\title{
KAROL WOJTYŁA I EMIL ZEGADŁOWICZ - BLISCY CZY DALECY? WOKÓŁ KONCEPCJI TEATRU
}

Postawione w tytule pytanie w pierwszej chwili może nasuwać jednoznaczną odpowiedź, zwłaszcza gdy weźmiemy pod uwagę ideowo-polityczne zwroty i dyskusyjne wystąpienia autora Zmór, jak też poważne kontrowersje towarzyszące recepcji jego dzieł. Co zatem - poza wspólnymi korzeniami wadowickiej ziemi może łączyć postaci, których artystyczne i życiowe drogi miały tak odmienny w swej istocie charakter? Karola Wojtyłę - poetę, dramaturga i aktora, teologa i filozofa, głowę Kościoła, wreszcie człowieka, który stał się wielkim autorytetem dla świata w czasach zaniku autorytetów, w epoce komercjalizacji i desakralizacji kultury oraz laicyzacji społecznego życia. I Emila Zegadłowicza, którego charyzmatyczna osobowość przyciągała wielu artystów, a całożyciowy dorobek poetycki, dramatopisarski, prozatorski i publicystyczny stanowi intrygujący splot antynomii, wymykając się jednoznacznym kwalifikacjom. Religijno-mistyczny sztafaż wczesnych poezji i dramatów, bezpośrednie zrośnięcie z regionalną kulturą, jak również bliska współpraca z klerykalnymi środowiskami Wielkopolski (m.in. z redakcją tygodnika „Tęcza”), włączyły autora Powsinogów beskidzkich w krąg tradycjonalistycznych wyznawców ludowości i czołowych pisarzy katolickich, natomiast późniejsze dzieła, wraz z postępującą w latach trzydziestych radykalizacją postawy politycznej, miały go naznaczyć stygmatem skandalisty, z polemicznym temperamentem godzącego w uznawane autorytety i narodową ideologię. Ambiwalentny wizerunek artysty podsycały też jego ożywione kontakty ze środowiskami lewicowymi, sprzyjające

Dr hab. AnNa PoDSTAwKa, prof. KUL - Katedra Dramatu i Teatru w Instytucie Literaturoznawstwa KUL; adres do korespondencji: Katolicki Uniwersytet Lubelski Jana Pawła II, Al. Racławickie 14, 20-950 Lublin; e-mail: anna.podstawka@kul.pl. ORCID: http://orcid.org/0000-0002-4681-9770. 
tworzonej przez powojenną krytykę legendzie pisarza-społecznika i zdeklarowanego socjalisty.

Nie ulega wątpliwości, że myślowy i artystyczny punkt dojścia w twórczości Zegadłowicza i Wojtyły (Jana Pawła II) był zdecydowanie odległy. Konstatacja ta nie wyklucza zarazem istnienia miejsc wspólnych, ukierunkowując badawczą refleksję na źródła, z jakich obaj twórcy czerpali kształtując swą poetycką wrażliwość, koncepcję człowieka i świata uzewnętrznianą via dramat, wpisaną w myśl teatralną, poglądy na temat misji sztuki i aktora. Nie jest to szlak zupełnie pomijany przez badaczy, w wielu miejscach pojawiają się wzmianki o kontaktach młodego Wojtyły z pisarzem uchodzącym za autorytet $\mathrm{w}$ sprawach literatury i sztuki, który potrafił stworzyć wokół siebie wyjątkowy artystyczny klimat, stanowiący część legendy starego, kamiennego dworu w Gorzeniu Górnym. Studium komparatystyczne, zakreślające „obszary wspólnych fascynacji i pola odrębnych rozstrzygnięć” w twórczości poetyckiej Zegadłowicza i Wojtyły, przedstawił ostatnio Stanisław Dziedzic (zob. 93-113). Ponadto wadowickie tropy młodzieńczej twórczości literackiej przyszłego papieża w szerszym, monograficznym aspekcie ujęła Marta Burghardt, charakteryzując zakres oddziaływania, na Wojtyłę i lokalne środowisko, licznego grona twórców pozostających w kręgu Zegadłowicza i grupy „Czartak”. „Można sądzić, że znał dobrze Zegadłowicza, bywał u niego, drzwi do jego domu stały otworem dla młodego Wojtyły" - utrzymuje badaczka, opierając się na ogólnych wspomnieniach świadków tamtych czasów (221)1.

Urodzony w 1888 roku Zegadłowicz, należał do pokolenia dojrzewającego w schyłkowej fazie Młodej Polski, a początki jego formacji artystycznej krystalizowały się z jednej strony pod silnym patronatem romantyków (m.in. idei genezyjskiej Słowackiego, dzieł Norwida) i modernizmu, z drugiej zaś wyrastały z ambicji orędowania „nowej sztuce”, we wczesnych latach międzywojennych skupionej wokół ekspresjonistycznego środowiska poznańskiego „Zdroju”. Podobnie jak u Wojtyły, nie do przecenienia jest wpływ, jaki na kształtowanie się młodzieńczego intelektu i wrażliwości miał ojciec Zegadłowicza, który przybył do Wadowic w 1868 roku, by podjąć pracę pedagoga w miejscowym gimnazjum, i wkrótce osiadł w pobliskim Gorzeniu Górnym (tu zmarł w roku 1899). Emil Zegadłowicz po uzyskaniu matury w 1906 roku rozpoczął studia na Wydziale Filozoficznym Uniwersytetu Jagiellońskiego. Jako główny kierunek wybrał polonistykę (dziejów literatury uczyli go profesorowie Marian Zdziechowski, Stanisław Tarnowski, Stanisław Windakiewicz,

\footnotetext{
${ }^{1}$ Mimo słynnego otwarcia gorzeńskiego dworu i mecenatu jego gospodarza dla licznych imprez kulturalnych, projektów artystycznych i wydawniczych, wydaje się, że częstotliwości tych kontaktów nie należy przeceniać. Z całą pewnością można natomiast stwierdzić kilka spotkań Wojtyły z Zegadłowiczem.
} 
Józef Tretiak, Ignacy Chrzanowski i Wilhelm Creizenach), którą porzucił po pierwszym semestrze, przenosząc się na historię sztuki². Jesienią 1938 roku w murach tego samego wydziału krakowskiej uczelni podjął studia polonistyczne Wojtyła, który swe zainteresowania humanistyczne, związane głównie z literaturą i teatrem, rozwijał pod patronatem młodszego pokolenia badaczy, uczęszczając na wykłady m.in. Stanisława Pigonia (teatr i dramat w Polsce od połowy XVIII wieku), Stefana Kołaczkowskiego (analiza teorii dramatu), Władysława Dobrowolskiego (interpretacja dramatyki - Wyspiański, Rostworowski) (zob. Popiel 256).

Uniwersytecka edukacja, połączona z działalnością w żywym teatrze ${ }^{3}$, stanowiła dopełnienie i kontynuację wcześniejszych doświadczeń scenicznych Wojtyły, którego zamiłowanie do teatru ukształtowały lata spędzone w Wadowicach. Jak podkreślał: „Zawsze mocno związany z miastem mojego dzieciństwa i wczesnej młodości, z miastem, które mi dużo, b.[ardzo] dużo dało. Mam wrażenie, że więcej niżby dać mógł Kraków. Oddech miasta i oddech ziemi, pewną prostolinijność w sposobie myślenia i niewątpliwy fundament kultury” („Listy Karola Wojtyły do Mieczysława Kotlarczyka" 362). Inteligencka atmosfera niewielkiego, za to prężnie rozwijającego się w okresie międzywojennym miasta, do czego przyczyniała się artystyczna aura pobliskiego Gorzenia, sprzyjała rozmaitym przedsięwzięciom kulturalnym, widocznym zwłaszcza w obszarze życia teatralnego. Ugruntowaną tradycję miał także teatr szkolny, chętnie przywoływany w papieskich wspomnieniach oraz relacjach jego wadowickich przyjaciół. Wedle pionierskich badań teatrologicznych Jana Ciechowicza, za debiut sceniczny Wojtyły „[...] można chyba przyjąć niemą rolę w Sobótce Kochanowskiego, widowisku plenerowym z ogniem i muzyką [...]. Przedstawienie to, pokazane w Zielone Świątki roku 1933 w Wadowicach, zostało powtórzone w Gorzeniu Górnym - a wszystko dla uczczenia 25-lecia pracy pisarskiej Emila Zegadłowicza” („Światopogląd teatralny Karola Wojtyły” 115). Rzeczywiście, w niezwykle bogatym programie lokalnych obchodów jubileuszu artysty (skumulowanych $\mathrm{w}$ dn. 4-5 czerwca) znalazło się kilka inicjatyw teatralnych, w tym wspomniany występ młodzieży wadowickich gimnazjów, męskiego i żeńskiego ${ }^{4}$. „Z Zegadłowiczem zaś i poezją grupy «Czartak» na pewno obcował Wojtyła z wyboru, ale niejako i z obowiązku” - dodaje badacz („Światopogląd teatralny Karola Wojtyły” 115), powołując się na dane zebrane przez Gustawa Studnickiego, według którego poeta

${ }^{2}$ Zegadłowicz zakończył uniwersytecką edukację w 1911 roku po dziesięciu semestrach studiów, jednak bez uzyskania dyplomu ich ukończenia (zob. Wójcik 43, 53).

${ }^{3}$ W styczniu 1939 roku Wojtyła włączył się w prace „Studia 39” Tadeusza Kudlińskiego, szkoły dramatycznej działającej przy Krakowskiej Konfraterni Teatralnej. Uczestniczył też w „lektoracie żywego słowa”, prowadzonym na Uniwersytecie Jagiellońskim przez Władysława Dobrowolskiego.

${ }^{4}$ Por. szczegółowe omówienie przebiegu uroczystości w monografii Mirosława Wójcika (304-306). 
utrzymywał żywe kontakty ze szkołami, co miały potwierdzać przykładowe wydarzenia z jego udziałem: 13 czerwca 1932 roku, kiedy wygłosił dla gimnazjalistów odczyt o Wyspiańskim 5 , 6 lutego 1935 roku, gdy młodzież uczestniczyła w wieczorze artystycznym urządzonym przez miejscowych artystów i literatów (por. Studnicki 23). Ponadto w grudniu 1932 roku - twierdzi Ciechowicz - „Wojtyła z pewnością oglądał Achilleis Wyspiańskiego z prelekcją Zegadłowicza, a w reżyserii Mieczysława Kotlarczyka” („Światopogląd teatralny Karola Wojtyły” 115-116) ${ }^{6}$.

Jak wiadomo, znajomość z późniejszym twórcą Teatru Rapsodycznego przerodziła się w wieloletnią przyjaźń, a teatralny mistrz z czasów wadowickich był pierwszym czytelnikiem i stałym powiernikiem literackiej pracy Wojtyły. Najprawdopodobniej jeszcze w Wadowicach powstał pierwszy jego tomik poetycki Ballady beskidzkie, tytułem nasuwający skojarzenie z twórczością Zegadłowicza, zapewne też - jak wnioskują Jacek Popiel, Marta Burghardt czy Stanisław Dziedzic - utrzymany w klimacie poezji „Czartaka”. Zbiorek ten nie został odnaleziony, można jednak przypuszczać, że zawierał utwory zatrzymane w pamięciowych impresjach uczestników spotkań poetyckich, podczas których Wojtyła z właściwą dlań charyzmą recytował swe wiersze (zob. Młodzieńcze lata) 7 . Z młodzieńczego okresu zachowała się natomiast ukończona wiosną 1939 roku Księga stowiańska, inaczej Psałterz Dawidów (przez Autora nazwany też Psałterzem bądź Renesansowym psałterzem). W księdze znalazł się m.in. cykl sonetów, których istotę ujmuje fragment autorskiego komentarza:

Sonety: Pieśni wiosny, wiosny roku tragicznego. Pieśni ufne we wigilią strasznych dni. Pieśni radosne nadzieją, pewnością, poczynaniem się - czegoś: widzenia - pragnienia, tęsknoty, dzieła. Pieśni - przeczucia. Sonety. - Z ziemi i nieba, z Boga i człowieka, z pogórzy i z drzew i z onych sobótek świętojańskich poczęte, zaczerpnięte, w ześpiew złożone. („Do sonetów!” 61)

Wiele już powiedziano na temat roli, jaką w biografii Wojtyły i Zegadłowicza (a szerzej: artystów „Czartaka”) odegrał beskidzki genius loci. W twórczości wadowickich poetów można dostrzec charakterystyczne odniesienia regionalne, umiłowanie prostoty, religijną pokorę, mistyczny związek z przyrodą. Wszak - jak głosił Zegadłowicz - tylko „we wspólności z ziemią, i z nią jedynie, duch krzepnie, nabiera

\footnotetext{
${ }^{5}$ Nie był to tylko jednorazowy wykład w wadowickim gimnazjum, utrzymującym bliską relację ze swoim znanym absolwentem. Wiosną 1932 roku Zegadłowicz odbył cykl odczytów dla uczniów małopolskich szkół średnich, zorganizowany z okazji obchodów roku jubileuszowego Wyspiańskiego (w 25-lecie śmierci artysty) (por. Wójcik 298).

${ }^{6}$ Kotlarczyk od 1931 roku kierował amatorskim Teatrem Powszechnym w Wadowicach, a Wojtyła zagrał w kilku jego przedstawieniach w latach 1937-1938. Zdaniem Marty Burghardt nie ma pewności, czy Wojtyła rzeczywiście oglądał spektakl Achilleis, ponieważ wydarzenie to miało miejsce 4 grudnia, w dniu śmierci jego brata Edmunda (Burghardt 170, 194).

${ }^{7}$ Spotkania te przywołuje m.in. wspomnienie Danuty Michałowskiej (Młodzieńcze lata 111-124).
} 
tężyzny i religijnieje w tych zmianach pór i lat, którymi Bóg rządzi!” („O kształtowaniu się idei” 64). „Ludowość to iście wiecznie żywa dziedzina, wiecznie nowymi sokami krzepiąca drzewo sztuki, które, ilekroć napływ tych soków jest możniejszy, tylekroć zakwita bujnie i owocuje nad podziw urodziwie" - dodawał w innym miejscu („Polski Faust i polski teatr” 105). To zakorzenienie odnosił też do dramatu, rodowodu i oparcia dla rodzimego teatru upatrując w tradycji ludowej utrwalonej „w szopkach, jasełkach, obrzędach dorocznych, dożynkach, wiankach, świętojankach i misteriach kalwaryjskich” („Polski Faust i polski teatr” 106). Afirmując w duchu franciszkańskim człowieka blisko obcującego z naturą, poeta zaludniał przestrzeń swych wierszy, dramatów i ballad misteryjnych wiejskimi powsinogami, odmieńcami, nawiedzonymi apostołami, którym bywa dane przeżycie duchowego wtajemniczenia, zbliżenia do prawd ostatecznych. „Beskid z nieogarnionym pięknem przyrody, legend, odrębności etnicznej mieszkańców, ich realizmem i mistycyzmem (społecznym i religijnym) stał się krainą wybraną poezji - i czymś więcej jeszcze - symbolem wolności i wzniosłości" - pisał w przedmowie do drugiego wydania Powsinogów beskidzkich $(7)^{8}$. Marta Burghardt, podjąwszy lekturę Wojtyłowych liryków z Księgi słowiańskiej w kontekście poezji Zegadłowicza, doszła do wniosku, że:

[...] liczne podobieństwa w podejmowanych tematach, w sposobie postrzegania otaczającego świata, opisywania uroku Beskidu, dostrzeganie Boga w przyrodzie, dominujące u obu [artystów - uzup. A.P.] elementy ludowości jak i słowa-klucze, przesądzają wręcz o ich wspólnocie w myśleniu i w obrazowaniu poetyckim. [...] Karol Wojtyła jako debiutujący poeta czerpał z Zegadłowicza głównie walory estetyczne, wzorował się na jego stylistyce, urzekła go jego spontaniczna ekspresja, ujawniająca duchowy klimat poety, głównie poprzez innowacje językowe [...]. $(229-230)^{9}$

\section{Nieco inaczej ujmuje tę kwestię Stanisław Dziedzic:}

Podobne pozostawały kierunki i sfery ich artystycznych penetracji, fascynacje i urzeczenia, ale mimo zbieżności w postrzeganiu małych ojczyzn oraz estetycznych kanonów piękna - odmienna

\footnotetext{
${ }^{8}$ Pierwsze wydanie ukazało się w 1923 roku. W okresie międzywojennym tomik poetyckich ballad miał kilka wznowień, w 1938 roku także w postaci „obrazków scenicznych w inscenizacji autora”, które powstały na potrzeby teatrów ludowych.

${ }^{9} \mathrm{~W}$ sferze oddziaływania na wrażliwość artystyczną Wojtyły badaczka umieszcza też innych regionalnych twórców, takich jak poeta Tadeusz Szantroch, malarz Wincenty Bałys czy słynny ludowy rzeźbiarz Jędrzej Wowro. Stosunek Wojtyły do Zegadłowicza w nieco innym świetle przedstawia wspomnienie Zofii Żarneckiej: „Nie pamiętam w jakich okolicznościach, ale na pewno wyrażał negatywną opinię o Zegadłowiczu (Zmory), wnosił zastrzeżenia co do formalnych i treściowych elementów Powsinóg beskidzkich. Powołując się na osobistą znajomość świątkarza Wowry, kwestionował sposób przedstawiania go przez Zegadłowicza. W opozycji do tego poety sam napisał Ballady beskidzkie (chyba tytuł cytuję wiernie). Nie spotkały się one jednak z przychylnym przyjęciem kolegów. Wydaje mi się, że dyskusje te miały miejsce w czasie zebrań Koła Studentów Polonistyki" (Kalendarium 42).
} 
była nie tylko retoryka ich utworów, lecz nade wszystko motywacje. Gdy Zegadłowicz zerwie z tradycjami czartakowskimi (choć przecież tego dziedzictwa się nie wyrzekł), Karol Wojtyła w grze żywiołów i błogosławionych mocy sztuki, umacniał będzie swe mistyczne doświadczenia. (111)

Zasadnicze różnice między wadowickimi twórcami zasadzały się w przekonaniach społecznych i politycznych, które u Zegadłowicza zmierzały w kierunku coraz ostrzejszego radykalizmu. Dla wadowiczan ewidentnym znakiem dokonującej się zmiany ideowej pisarza była wydana w 1935 roku powieść Zmory, obnażająca mechanizmy funkcjonowania prowincjonalnego środowiska, propagująca postawę anarchizmu i antyklerykalizmu - z pewnością czytana też przez młodego Wojtyłę. Wojnę wypowiedzianą społecznej hipokryzji podtrzymywał także reportażowy Pokój dziecinny (1936), dramat powstały w kontekście burzliwej polemiki na temat wycofanych z oficjalnego obiegu czytelniczego Zmór. „Z religijnego Pawła zmienił się Zegadłowicz w racjonalistycznego Szawła" - skomentował jeden z badaczy (Studencki 111), jakkolwiek trzeba zaznaczyć, że krytyka wypaczeń instytucji życia społecznego obecna była w twórczości pisarza z różnym nasileniem niemal zawsze. Wyznając aktywną postawę ewangeliczną wraz z indywidualistycznym subiektywizmem w przeżywaniu wiary, żywą religię konfrontował on z wyznaniowymi podziałami, hierarchią i anachronizmem kościelnej instytucji. W Pokoju dziecinnym wprost już proklamował ,anarchizm zdyscyplinowany etyką” (24), wieszcząc nadejście nowej ery ludzkości, „w której nie będzie narodów i państw, wyznań ni kościołów, przemocy ni nienawiści” (70).

Pomimo oczywistych światopoglądowych rozdźwięków obaj artyści głęboko wierzyli w moc słowa poetyckiego oraz wyjątkowość poznawczych predyspozycji literatury, odbierając sztukę i rolę poety jako misję, zespolenie ,wypracy” fizycznej z duchową, z pełną odpowiedzialnością za treść i formę przekazu. Pojmowana na sposób antyczny paideia poety łączy się też z formą teatralną, zarówno dla Zegadłowicza, jak i Wojtyły będącą integralnym dopełnieniem twórczości poetyckiej. ,[...] tkwi we mnie falanga pomysłów, zaledwie przeczutych, napunktowanych, trzeba by im spokoju i pracy i dojrzałości. Widzisz, ja się w tych wierszach po prostu uczę mówić, zanim zacznę rozmawiać. Zresztą myślę obrazami b. [ardzo] teatralnymi. Zwrócił już na to uwagę swego czasu Emil Zegadłowicz"10 pisał w listopadzie 1939 roku Wojtyła do Kotlarczyka, równocześnie zapewniając:

Wierzę w Twój teatr i chciałbym go koniecznie współtworzyć, bo on byłby różny od wszystkich „polskich” i nie łamałby człowieka, ale podnosił i zapalał i nie psuł, ale przeanielał. („Listy Karola Wojtyły do Mieczysława Kotlarczyka” 351-352)

\footnotetext{
${ }^{10}$ Niewykluczone, że wspomniany przez Wojtyłę komentarz poety dotyczył utworów ze zbiorku Ballad beskidzkich.
} 
I zawsze jestem przy Tobie, Bracie mój, jako był Jan Apostoł przy Piotrze, a Piotr był opoką, a na tej opoce zbudowan Kościół Jego, a Kościołem Jego niech się stanie Teatr i...

... i niechaj w nim rozjarzy - w zborze, w sejmie jakoby narodowej sztuki, Narodowy Duch; ten, co tęskni i płonie, a nie co frymarczy i kupczy. („Listy Karola Wojtyły do Mieczysława Kotlarczyka" 348)

W tym okresie, w obliczu doświadczenia wojny i okupacji, Wojtyła kształtował swe poglądy na temat roli literatury, teatru i aktora w społeczeństwie. Wyrastały one na fundamencie wiary w moc sztuki, która ,jest spojrzeniem w przód i wzwyż, jest towarzyszką religii i przewodniczką na drodze ku Bogu”, sztuki wiodącej „od ziemi i od serca człowieczego ku Nieskończonemu” i tym samym otwierającej „horyzonty przeogromne, metafizyczne i anielskie” („Listy Karola Wojtyły do Mieczysława Kotlarczyka” 350). Krytyczny wobec profilu repertuarowego forującego „rozbudowany wodewilizm" (344), poszukiwał własnej drogi artystycznej, rozmyślając nad kształtem polskiej sceny:

Otóż chodzi o pieśń polskim i słowiańskim duchem przepojoną. [...] bo Piękno nasze i sztuka nasza z naszego jest Narodu i dla naszego Narodu: to jest pieśn Wieszczów, Teatr Wyspiańskiego, Księgi Kasprowicza i filozofia Norwida. W nich jest linia wielkiej poezji polskiej, pieśń nie przebrzmiała, która naród jak w owym Genezis z Ducha mocą wypracy i ofiary ku górze prowadziła i ku wyzwoleniu, a w powojennej: import, szmonces, komedia głupawa i sprośna i wszystko takie nie-nasze, nie-polskie, nie-słowiańskie, nie-Chrystusowe i nie-Boże.

Trza się odrodzić i odróżnić. („Listy Karola Wojtyły do Mieczysława Kotlarczyka” 350-351)

Przemyślenia młodego Wojtyły warto zestawić z Zegadłowiczowską koncepcją teatru, wywiedzioną z duchowej spuścizny wykładów Mickiewiczowskich oraz idei teatru słowiańszczyzny, dojrzewającą pod wpływem dzieł romantyków i Wyspiańskiego, a także własnych doświadczeń pracy dramatopisarskiej i udziału w życiu artystycznym pierwszych lat niepodległej Polski, w tym trzech sezonów (od września 1927 do końca sierpnia 1930 roku) na stanowisku kierownika literackiego w Teatrze Polskim w Poznaniu (por. Podstawka, „«Uświęcać pospolitość» - Emila Zegadłowicza koncepcja teatru" 57-75). Jako sukcesor Wyspiańskiego, symbolicznie namaszczony przez Karola Huberta Rostworowskiego podczas krakowskiej prapremiery Lampki oliwnej 31 maja 1924 roku $^{11}$, Zegadłowicz poczuwał się do podtrzymywania etosu teatru, w którym - jak chciał Tadeusz Miciński - akcja dramatyczna tocząca się wokół ofiarnego ołtarza ma prowadzić do „wtajemniczeń człowieka w głębiny

${ }^{11}$ Lampka oliwna, wystawiona w Teatrze im. J. Słowackiego w reżyserii Stanisławy Wysockiej, była scenicznym debiutem poety. Rostworowski, uznawany przez krytykę za spadkobiercę Wyspiańskiego, w wygłoszonym podczas premiery przemówieniu uroczyście przekazał Zegadłowiczowi swoje „berło poetyckie”. 
i podziemia duszy" $(1)^{12}$. W epilogu Zegadłowiczowskiego „misterium balladowego” Nawiedzeni jest mowa o dramacie, w którym ,akcja jakoś płynie skrycie / podziemiami nierealnie" (121). Słowa te warto dopełnić fragmentem poetyckiego prologu:

[...] dopóki

nie zrozumiemy tej nauki,

że scena to jest święta rzecz,

że scena to jest ołtarz boży,

że scena znaczy „wprzód” lub „wstecz”,

że scena znaczy „lepiej”, ,gorzej”,

że scena to nadsłuchiwanie,

że scena to jest - zmartwychwstanie -

- trudno i darmo - bo dopóki

nie zrozumiemy tej nauki,

jaką nam Grecja przekazała,

jaką nam dało średniowiecze -

na nic dyskusja nasza cała

i na nic wszystkie sny człowiecze - (,Nawiedzeni” 10)

W napisanym w 1929 roku dla poznańskiej sceny Aktorze wiecznym poeta bezpośrednio nawiązywał do idei „teatru-świątyni ducha” i aktorstwa jako kapłaństwa, podkreślając „świętą misję teatru”, „posłannictwo sceny”, która ma „wskrzeszać, budzić, podnosić, / wzruszać - słowo głosić - / siać entuzjazm, jak zboże / i duchy unosić / w nieogarnione przestworze" (s. nlb.) ${ }^{13}$. Ze sceny Teatru Polskiego proklamował, że „teatr jest wyrazem instynktu ludzkiego, jest zbiorowym zespoleniem duchów i czymś więcej jeszcze: najwyższą formą religijnego doznania”, a ponieważ religijne formuły wypowiadania się skostniały w swej obrzędowej tożsamości, to „wielkie odrodzenie etyczne ludzkości [...] pocznie się nie gdzie indziej jak właśnie w teatrze” („Na otwarcie Teatru Polskiego” 2) ${ }^{14}$. Kilka lat wcześniej na łamach Listów z Teatru pisał: „kto zrozumie, czym jest msza śpiewana dla kamieniotłuka, łupiącego przez sześć dni tygodnia oporny zlepieniec - ten zrozumie też powinności i cechy zjawiska zwanego teatrem”, który ,jest tajemnicą, jak Przemienienie Pańskie”, „podniesieniem do potęgi wszelkich przejawów człowieczego bytowania, rozszerzeniem bytu jednostki poza materialne zjawiska” („W obliczu gór i kulis”

${ }^{12}$ Artykuł Micińskiego Teatr świątynia został opublikowany w lwowskim Stowie Polskim 4 maja 1905 roku, w związku z dyskusjami wokół starań Wyspiańskiego o dyrekcję Teatru Miejskiego w Krakowie. Późniejszy przedruk w antologii Myśl teatralna Młodej Polski w wyborze Ireny Sławińskiej i Stefana Kruka (1966) utrwalił formę tytułowego zapisu Teatr-Światynia.

${ }^{13}$ Prolog powstał z okazji uroczystego otwarcia sezonu Spazmami modnymi Wojciecha Bogusławskiego w Teatrze Polskim w Poznaniu dnia 1 października 1929 roku. Widowisko było hołdem złożonym artyście w stulecie jego śmierci.

${ }^{14}$ Słowo wstępne wygłoszone podczas inauguracji nowego sezonu w dniu 28 września 1928 roku. 
8-9) ${ }^{15}$. Mówiąc o narodowym teatrze, Zegadłowicz często odwoływał się do języka liturgii, za pomocą słowa kreując nową, nacechowaną sakralnie rzeczywistość:

Cisza!... cyt!... szelest kart księgi...

Wszyscy tam klęczą na scenie -

jakby ksiądz podniósł monstrancję -

- to msza! - to msza!! - podniesienie!!!

$[\ldots]$

Zaczyna się widowisko

sceną wieczystej unii --

Bóg konsekruje opłatki

jutrzejszej duchów komunii - - („Noc czerwcowa MCMXXVII”33)

Tak oto w świetle tajemnicy misterium poeta przeżywał inscenizacje wielkich dzieł Słowackiego, w poetyckiej retoryce porównując sceny do modlitw, a myśli słuchaczy do psalmów. Świat doznań religijnych, wyrastający z przekonania o silnych związkach liturgii ze sferą teatralnego misterium, bliski był również młodemu Wojtyle. „A przecież liturgia jest także pewnego rodzaju mysterium granym, inscenizowanym" - stwierdzał w przywoływanym po latach wspomnieniu Triduum Sacrum z katedry wawelskiej, w którym uczestniczył jako piętnastoletni chłopiec: „To był dla mnie duchowy wstrząs. Triduum paschalne jest dla mnie do dzisiaj wstrząsającym przeżyciem" (Jan Paweł II 77).

„Niewiele potrafimy powiedzieć o przedwojennych upodobaniach teatralnych Wojtyły" - uznał Jacek Popiel, wyłuskując pośrednie informacje ze wzmianek rozsianych w okupacyjnych listach do Kotlarczyka, w których wybrzmiewa zatroskanie o kształt przyszłej polskiej sceny (261). Prawdziwy teatr „był u Wyspiańskiego i poza Wyspiańskiego nikt nie poszedł" - uważał Wojtyła, wyrażając zarazem obawę, „czy się znów nie namnoży Szyfmanów i Zelwerowiczów, różnych Sobańskich” („Listy Karola Wojtyły do Mieczysława Kotlarczyka” 350, 352). W przypadku Zegadłowicza teatralne fascynacje i oceny osiągnięć polskiej literatury miały zdecydowanie kosmopolityczne zabarwienie, jednak i w jego licznych wypowiedziach z lat dwudziestych ujawnia się negatywny stosunek do komercyjnej linii repertuarowej opartej na komedii i farsie, wskutek czego „teatr jest kapłanem podejrzanego gatunku, trochę stręczycielem i nieodpowiedzialnym, złym, czasem przewrotnym pedagogiem”. Tymczasem - jak przekonywał - „teatr ma wznosić [...] kształcić [...] wychowywać i darzyć wzruszeniami bliźniaczymi wzruszeniom religijnym" („Polski Faust i polski teatr” 108). W ujęciu poety odnowione miało być przede wszystkim rozumienie sztuki teatralnej, funkcji dramatu, sposobu uczestniczenia

${ }^{15}$ Pierwodruk artykułu: Listy z Teatru, nr 5, 1925, ss. 125-131. 
odbiorcy w spełniającym się ,,wielkim misteryjnym porozumieniu”, gdzie „tajemniczą spójnią" pomiędzy widzami a sceną jest „,wzniosła mowa poezji, której słowna eksplozja, poczęta w śpiewie aktora, eksploduje w sercu widza - niszcząc skorupę powszedniości codziennej” (cyt. za: Wójcik 232) ${ }^{16}$. Znaczącym kontekstem dla tych wypowiedzi mogą być późniejsze słowa Mieczysława Kotlarczyka, że „przeznaczeniem teatru jest pomagać ludzkości w jej wielowiekowej wędrówce ku Bogu, rzucać człowieka w strefy ponadmaterialnych płaszczyzn" (cyt. za: Ciechowicz, „Reduta słowa” 389) ${ }^{17}$. Przywołane tu refleksje wyraźnie określają soteriologiczny wymiar sztuki teatralnej, a obaj artyści niezależnie od siebie podnoszą - bliską również Wojtyle - etyczną moc teatru otwierającego przed publicznością horyzont transcendencji, ukazującego rzeczywistość duchową i poetycką.

Wskazując na „miejsca wspólne” Zegadłowiczowskiego i Wojtyłowego myślenia o teatrze, nie można pominąć wyjątkowej atencji dla teatru Wyspiańskiego, uznania jego przełomowej roli w historii narodowej sceny. W przemówieniu upamiętniającym dwudziestą rocznicę śmierci artysty Zegadłowicz nie pozostawiał wątpliwości, „że Wyspiański otworzył drzwi teatrowi polskiemu, że stworzył przed nim wielkie powietrzne przestrzenie - że od niego zaczyna się świadoma, twórcza praca nad odrodzeniem i stworzeniem sceny polskiej w jej zagadnieniu najwyższym: oratoryjnym i misteryjnym” („Czyn Wyspiańskiego” 165). W dziele Wyspiańskiego upatrywał początek rewolucji wizji dramatycznej, wiodącej ku sferom dotykającym najwyższych zagadnień i doznań religijnych, „łączącej poprzez prymityw jasełkowy, świat zjaw, antyk, zagadnienia społeczne - Polskę z Bogiem, naród z państwem, widowiskowość malarską z oratorium misteryjnym”, z którą ,,mierzyć się nie może żaden z dotychczasowych przełomów w zakresie Teatrum dokonanych” („Czyn Wyspiańskiego" 163$)^{18}$.

Dramatopisarski rozdział w dorobku literackim Zegadłowicza, w głównej mierze realizujący się w latach dwudziestych, stanowił świadomą próbę urzeczywistnienia koncepcji teatru religijnego. W styczniu 1924 roku ukazało się drukiem jego pionierskie „misterium balladowe” Noc świętego Jana Ewangelisty, później włączone jako trzecia odsłona do pięcioaktowej Wigilii (pierwotnie: $O$ wiekuistej tęsknocie, 1927). Te dwa dramaty misteryjne zakreślają pierwszy etap etyczno-artystycznego programu poety, w którym znaczące miejsce zajmuje powstały w okresie 1924-1925

\footnotetext{
${ }^{16}$ Fragmenty przemówienia Zegadłowicza przygotowanego na otwarcie nowego sezonu w Teatrze Polskim w Poznaniu w dniu 1 października 1929 roku.

${ }^{17} \mathrm{Z}$ odczytu Kotlarczyka o teatrze narodowym „Wyspiański: O polski charakter teatru”, wygłoszonego w 1933 roku w Wadowicach (rkps ze zbiorów Zofii Kotlarczykowej).

${ }^{18} \mathrm{~W}$ pierwszych latach niepodległej Polski poeta ważne miejsce przyznawał działalności Reduty, szansę na wykształcenie rodzimej formy teatralnej dostrzegał w inscenizacjach Leona Schillera, cenił również aktorskie i reżyserskie osiągnięcia Stanisławy Wysockiej.
} 
beskidzki tryptyk: Nawiedzeni, Lampka oliwna i Głaz graniczny, a także kolejne utwory tworzone z myślą o scenie: m.in. antyczna Alcesta (1925), biblijna Betsaba (1926) czy wzorowane na Betlejem polskim Lucjana Rydla widowisko jasełkowe Gdy się Chrystus rodzi... (1927). Pozostając w kręgu oddziaływania ekspresjonizmu, Zegadłowicz zdecydowanie odchodził wtedy od sztuki werystycznej, intelektualnej i zracjonalizowanej, dlatego podejmowane nieraz próby odczytania jego dramatów w kluczu poetyki naturalistycznej, pomimo pozornej bliskości tematycznej, okazują się niewystarczające. Działania dramatis personae nie są oparte na logice przyczynowo-skutkowej, wydarzenia zostały osadzone w wiecznym „teraz”, a przestrzeń sceniczna zyskuje wymiar sakralnego centrum (por. Olszewska 298-323; Podstawka, „Sacrum w dramaturgii Emila Zegadłowicza” 251-270). Poeta w obrębie struktury utworów dramatycznych dokonuje treściowego zespolenia wątków i odniesień regionalnych z płaszczyzną kultury uniwersalnej, otwierającą metafizyczny horyzont świata poetyckiego, gdyż - jak pisał - „wszelki czyn, odkupienie i ofiara musi mieć na mapie kosmicznej i swoje Betleem i swój Nazaret” („O Legionie czartakowskim” 185). Nawiązując zwłaszcza do tradycji misteryjno-moralitetowej, eksperymenty formalne traktował jako pochodną poszukiwań środków wyrazu przybliżających do prawd pierwszych i ostatecznych. „Treść jest wszystkim; o nią w sobie walczymy; forma jest ciałem, treść duchem kształtującym powłokę swą wedle miary i potrzeby" („O Legionie czartakowskim” 183).

W zasięgu promieniowania czartakowskich idei teatralnych pozostawał też młody Wojtyła, dla którego były one elementem doświadczeń przekuwanych we własną filozofię teatru w perspektywie antropologicznej, wyrażającego duchowe potrzeby współczesnego świata, wnikającego w intymną przestrzeń relacji między człowiekiem a Bogiem. Dramaturgiczne juwenilia autora Brata naszego Boga, powstające na przełomie 1939 i 1940 roku, mają charakter tekstów napisanych z myślą o ich wystawieniu w teatrze poetyckim, którego przyszły kształt wyłaniał się pod wpływem okupacyjnych medytacji oraz dyskusji z Kotlarczykiem, a także poznanym wówczas Juliuszem Osterwą. Tematykę pierwszego, zaginionego utworu znamy jedynie ze wzmianek i relacji Autora: „Napisałem dramat, ściślej poemat dramatyczny. Nazywa się Dawid, chodzi w stroju biblijnym i w piastowskiej płótniance i w karmazynowej delii. Wiele rzeczy, wiele spraw duszy swojej w nim objawiłem". Kolejne dramaty również są realizacją wątków starotestamentalnych: Hiob, „grecki formą, chrześcijański duchem, odwieczny treścią, podobnie jak Każdy”, oraz Jeremiasz, który „powstał błyskawicznie jako objawienie podczas czytania Proroctw Jeremiasza” („Listy Karola Wojtyły do Mieczysława Kotlarczyka” 353, 355-356, 358).

Odautorskie, lakoniczne komentarze wskazują istotne źródła, z których czerpał Wojtyła-dramaturg. Już w pierwszej lekturze skupionej na zewnętrznej tkance dzieła nietrudno stwierdzić, że struktura i problematyka jego wczesnych utworów scenicz- 
nych ma mocne zakorzenienie w tradycji antycznej i misteryjno-moralitetowej. Na klasycznym modelu greckiego teatru opiera się zwłaszcza Hiob, rozgrywający się w monumentalnej przestrzeni scenicznej (stopnie proste kondygnacja, tho we trzy przedzielone ścienice, przedzielone zasię kolumnami, prostych kolumn dwojgiem wytyczone - 115), z precyzyjną konstrukcją zdarzeniową spiętą wystąpieniami Prologosa i Epilogosa, obecnością chóru komentującego i uczestniczącego w akcji. Kondygnacyjna organizacja przestrzeni, nawiązująca z kolei do konwencji sceny misteryjnej, od początku zakotwicza świat poetycki dramatu w porządku wertykalnym. Obraz zespolenia nieba z ziemią nabiera pełnej konkretyzacji w końcowej części Hioba, antycypującej nadejście Syna Bożego: Poza zasłony środkowej rozdarciem ukazuja się stopnie w górę wiodace. Na stopniach tych smuga świetlna się kładzie (169). Szczególne znaczenie ma tutaj mistyka światła, tak charakterystyczna również dla dramatów Wyspiańskiego, niewątpliwie znacząco oddziałujących na kształtowanie się wizji teatralnej Wojtyły. Jaśniejący spoza zasłony świt, z wyłaniającym się w pewnym momencie kształtem krzyża, posiada uderzające nacechowanie symboliczne, odsłaniając horyzont duchowej ciągłości świata także za pomocą znaków pozasłownych, precyzyjnie wpisanych w obraz przestrzeni. Zwielokrotnione niczym refren uwagi w didaskaliach o, ,jaśni świtania” wykraczają poza funkcję inscenizacyjnych wskazówek, stanowiąc integralny, nasycony semantycznie element tekstu poetyckiego - ta właściwość Wojtyłowej dramaturgii dodatkowo wskazuje na bliskie powinowactwa z Wyspiańskim.

Podobne spostrzeżenia $\mathrm{w}$ aspekcie operowania światłem jako środkiem teatralizacji oraz kompozycji i roli didaskaliów można odnieść do dramatów misteryjnych Zegadłowicza, w wielu miejscach skrywających podskórny, metafizyczny puls akcji, a ponadto wprowadzanych $w$ formie wyodrębnionych $\mathrm{z}$ tekstu poetyckich prologów czy też międzyaktowych komentarzy, które nadbudowują transcendentny wymiar rzeczywistości (np. w Nawiedzonych, Lampce oliwnej). Horyzontalny układ przestrzeni nieustannie krzyżuje się z szerszym porządkiem wertykalnym, odsłaniającym duchową kondycję dramatis personae. W jednej ze scen biblijnej Betsaby, będącej dramatyczną reinterpretacją starotestamentalnej historii miłości izraelskiego króla Dawida i żony Uriasza, władca schodzi z pałacowego tarasu, łącząc się z Betsabą w połowie stopni, a podczas ich rozmowy na niebie jawi się $w$ dalekim rozedrganiu - prawie że tylko dla tych dwojga widoczny miraż: wizja biatego miasta (zob. 184-187). Czas ziemskiego hic et nunc niepostrzeżenie stapia się z czasem metafizycznym, uobecnionym w przeczuwanym misterium narodzin Chrystusa, które wytycza zbawczy horyzont dziejów ludzkości, dopełniony słowami proroka. Skrucha Dawida i Betsaby splata się z apologią ich uczucia, a pojawiająca się w epilogu świetlista wizja betlejemskiej stajenki nie pozostawia wątpliwości, że przyszłość świata zależy od miłości, ale nie w ludzkim, tylko w Bożym jej wymiarze. 
W ludowej Lampce oliwnej świat transcendencji reprezentowany jest symbolicznym rekwizytem wiecznego światełka, rozjaśniającego mroczną przestrzeń chałupy, oraz obrazami domowych świątków, będących materialnym znakiem obecności sił nadprzyrodzonych. Stylizowane na grecki chór postaci, z kąta ku środkowi izby przymykajace zwidziadła święte (129), są dyskretnymi obserwatorami rodzinnej tragedii, odniesieniem do odrzuconej przez człowieka sfery kryteriów moralnych. Analogiczne zróżnicowanie dramatis personae ze względu na ich status ontologiczny wprowadził Wojtyła w Jeremiaszu, ożywiając figury ołtarzowych rzeźb. Prologową funkcję celebransów rozgrywającego się w scenerii kaplicy teatralnego misterium pełnią dwaj biali aniołowie, obdarzeni mocą sprawczą, by z wysokości kolumn „też w inne kłaść życie kamienie” (183). Świat widzeń konkretyzuje się w odsłoniętym przez nich ołtarzu, w którego rzeźbach wyciosane są postacie z Jeremiaszowych proroctw, zyskujące rangę pełnoprawnych osób dramatu (zob. 183-184). Nie mniej interesującą płaszczyzną dramaturgii Wojtyły i Zegadłowicza jest organizacja warstwy słownej, którą warto by przeanalizować pod kątem oratoryjnej instrumentacji muzyczno-językowej, realizowanej (zwłaszcza w Hiobie, Jeremiaszu czy Betsabie) w różnych odmianach sekwencji chóralnych, deklamacyjnie zestrojonych dialogach-duetach, monologowych lamentacjach, śpiewach trenów Jeremiaszowych i psalmów Dawidowych.

Rekonesansowa próba porównania kompozycji dramaturgii Zegadłowicza i Wojtyły, ograniczona do kilku przykładów, wskazuje na możliwości kontynuacji tego tropu badawczego, dopełnienia sygnalnych uwag o bardziej precyzyjne rozpoznania opierające się na całościowej analizie struktury dzieła. Jednak już wyimkowy obszar badań określa wspólne korzenie, źródła postrzegania roli teatru i model dramaturgii wyrastającej z tradycyjnych form teatralnych, pozostającej na obrzeżach poszukiwań awangardy. Podsumowując trudno nie zgodzić się z konkluzją Stanisława Dziedzica, wskazującego podobne kierunki i obszary artystycznych penetracji wadowickich twórców, pojmowania estetycznych kanonów sztuki, wartości regionalnej kultury, przy równoczesnej odrębności ich światopoglądu i twórczości. „W przeciwieństwie do Emila Zegadłowicza, targanego namiętnościami, głębokimi antynomiami, pełnego uderzających niekonsekwencji w postępowaniu, Karol Wojtyła w swoim artystycznym i intelektualnym rozwoju zachowywał konsekwencję i tożsamość" (112). Potwierdzają to również późniejsze osiągnięcia w dziedzinie dramatu, które dla Wojtyły były integralnym dopełnieniem personalistycznej refleksji filozoficznej i teologicznej (trylogia Promieniowanie ojcostwa, Brat naszego Boga, Przed sklepem jubilera), natomiast w przypadku Zegadłowicza stawały się polemicznym poligonem, coraz ostrzejszą próbą diagnozy współczesnej rzeczywistości społecznej i politycznej. 


\section{BIBLIOGRAFIA}

Burghardt, Marta. Wadowickie korzenie Karola Wojtyty. Wadowickie Centrum Kultury im. Marcina Wadowity, 2013.

Ciechowicz, Jan. „Reduta słowa. Dogmat i świętość w Teatrze Rapsodycznym”. Dramat i teatr religijny w Polsce, red. Irena Sławińska i Wojciech Kaczmarek, Towarzystwo Naukowe KUL, 1991, ss. $387-400$.

Ciechowicz, Jan. „Światopogląd teatralny Karola Wojtyły”. Jan Ciechowicz. Dom opowieści. Ze studiów nad Teatrem Rapsodycznym Mieczysława Kotlarczyka. Wydawnictwo Uniwersytetu Gdańskiego, 1992, ss. 114-128.

Dziedzic, Stanisław. „Emil Zegadłowicz i Karol Wojtyła. Obszary wspólnych fascynacji i pola odrębnych rozstrzygnięć”. Emil Zegadłowicz. Daleki i bliski, red. Henryk Czubała, Krzysztof Kłosiński, Krystyna Latawiec i Włodzimierz Próchnicki, Wydawnictwo Uniwersytetu Śląskiego, 2015, ss. 93-113.

Jan Paweł II. Wstańcie, chodźmy! Wydawnictwo św. Stanisława BM Archidiecezji Krakowskiej, 2004.

Kalendarium życia Karola Wojtyly, oprac. Adam Boniecki, Znak, 1983.

„Listy Karola Wojtyły do Mieczysława Kotlarczyka z okresu wojny i okupacji”. Dzieła literackie i teatralne, t. 1: Juwenilia (1938-1946), red. Jacek Popiel i in., Znak, 2019, ss. 343-365.

Miciński, Tadeusz. „Teatr świątynia”. Słowo Polskie, nr 207, 1905, ss. 1-2.

Młodzieńcze lata Karola Wojtyły. Wspomnienia, red. Juliusz Kydryński, Oficyna Cracovia, 1990.

Olszewska, Maria Jolanta. „Ballady misteryjne Emila Zegadłowicza”. Maria Jolanta Olszewska. „, Tragedia chłopska”. Od W.L. Anczyca do K.H. Rostworowskiego. Tematyka-kompozycja-idee. Nakładem Wydziału Polonistyki Uniwersytetu Warszawskiego, 2001, ss. 298-323.

Podstawka, Anna. „Sacrum w dramaturgii Emila Zegadłowicza”. Religijność na progu nowoczesności. O literaturze polskiej lat 1918-1945, red. Mirosława Ołdakowska-Kuflowa i Lech Giemza, Towarzystwo Naukowe KUL, 2010, ss. 251-270.

Podstawka, Anna. „»Uświęcać pospolitość« - Emila Zegadłowicza koncepcja teatru”. W kręu polskiego dramatu i teatru religijnego XX wieku, red. Wojciech Kaczmarek i Joanna Michalczuk, Norbertinum, 2007, ss. 57-75.

Popiel, Jacek. „Teatr w biografii Karola Wojtyły”. Jacek Popiel. Los artysty w czasach zniewolenia. Teatr Rapsodyczny 1941-1967. Wydawnictwo Uniwersytetu Jagiellońskiego, 2006, ss. 247-292.

Studencki, Władysław. Twórczość dramatyczna Emila Zegadłowicza. Zakład Narodowy im. Ossolińskich - Wydawnictwo, 1962.

Studnicki, Gustaw. Pierwsza wśród równych. Dzieje Gimnazjum i Liceum w Wadowicach. Towarzystwo Miłośników Ziemi Wadowickiej, 1991.

Wojtyła, Karol. „Do sonetów!”. Dzieła literackie i teatralne, t. 1: Juwenilia (1938-1946), red. Jacek Popiel i in., Znak, 2019, ss. 61-62.

Wojtyła, Karol. „Hiob. Drama ze Starego Testamentu”. Dzieła literackie i teatralne, t. 1: Juwenilia (1938-1946), red. Jacek Popiel i in., Znak, 2019, ss. 113-175.

Wojtyła, Karol. „Jeremiasz. Drama narodowe we trzech działach”. Dzieła literackie i teatralne, t. 1: Juwenilia (1938-1946), red. Jacek Popiel i in., Znak, 2019, ss. 177-245.

Wójcik, Mirosław. Pan na Gorzeniu. Życie i twórczość Emila Zegadłowicza. Wydawnictwo Akademii Świętokrzyskiej, 2005.

Zegadłowicz, Emil. Aktor wieczny. Rolnicza Drukarnia Nakładowa i Księgarnia Nakładowa, 1929.

Zegadłowicz, Emil. „Betsaba. Dramat w trzech aktach z epilogiem”. Emil Zegadłowicz. Dramaty, t. 2, Wydawnictwo Drukarni Nakładowej Józefa Kawalera, 1932, ss. 131-250.

Zegadłowicz, Emil. „Czyn Wyspiańskiego. Przemówienie wygłoszone 27 listopada 1927 roku na akademii w Teatrze Polskim w Poznaniu w dwudziestą rocznicę śmierci Wyspiańskiego”. Emil 
Zegadłowicz. W obliczu gór i kulis. Fiszer i Majewski Księgarnia Uniwersytecka w Poznaniu, 1927, ss. 153-168.

Zegadłowicz, Emil. „Lampka oliwna. Tragedia w trzech aktach”. Emil Zegadłowicz. Dramaty, t. 1, Wydawnictwo Drukarni Nakładowej Józefa Kawalera, 1932, ss. 123-205.

Zegadłowicz, Emil. „Na otwarcie Teatru Polskiego”. Dziennik Poznański, nr 227, 1928, s. 2.

Zegadłowicz, Emil. „Nawiedzeni. Misterium balladowe w trzech aktach”. Emil Zegadłowicz. Dramaty, t. 1, Wydawnictwo Drukarni Nakładowej Józefa Kawalera, 1932, ss. 5-122.

Zegadłowicz, Emil. „Noc czerwcowa MCMXXVII”. Emil Zegadłowicz. W obliczu gór i kulis. Fiszer i Majewski Księgarnia Uniwersytecka w Poznaniu, 1927, ss. 25-33.

Zegadłowicz, Emil. „O kształtowaniu się idei. Odczyt wygłoszony w Kole Polonistów Uniwersytetu Poznańskiego 12 maja 1927 roku”. Emil Zegadłowicz. W obliczu gór i kulis. Fiszer i Majewski Księgarnia Uniwersytecka w Poznaniu, 1927, ss. 35-91.

Zegadłowicz, Emil. „O Legionie czartakowskim. Przedmowa do rocznika „Czartaka” zboru poetów w Beskidzie na rok 1928, wygłoszona na wieczorze czartakowskim urządzonym staraniem Koła Polonistów Uniwersytetu Poznańskiego dnia 14 listopada 1927 roku”. Emil Zegadłowicz. W obliczu gór i kulis. Fiszer i Majewski Księgarnia Uniwersytecka w Poznaniu, 1927, ss. 177-187.

Zegadłowicz, Emil. Pokój dziecinny. Dramat. Biblioteka Gorzeńska, 1936.

Zegadłowicz, Emil. „Polski Faust i polski teatr. Odczyt wygłoszony w Kole Polonistów Uniwersytetu Poznańskiego dnia 14 maja 1927 roku". Emil Zegadłowicz. W obliczu gór i kulis. Fiszer i Majewski

Księgarnia Uniwersytecka w Poznaniu, 1927, ss. 93-123.

Zegadłowicz, Emil. Powsinogi beskidzkie. Drukarnia Franciszka Foltina, 1924.

Zegadłowicz, Emil. „W obliczu gór i kulis. Z listów do przyjaciół”. Emil Zegadłowicz. W obliczu gór $i$ kulis. Fiszer i Majewski Księgarnia Uniwersytecka w Poznaniu, 1927, ss. 3-15.

\section{KAROL WOJTYŁA I EMIL ZEGADŁOWICZ - BLISCY CZY DALECY? WOKÓŁ KONCEPCJI TEATRU}

\section{Streszczenie}

Artykuł jest komparatystycznym studium na temat koncepcji teatru Karola Wojtyły i Emila Zegadłowicza. Mimo iż powstaje wiele prac poświęconych młodzieńczej twórczości literackiej i działalności teatralnej Wojtyły, wciąż nie w pełni przeanalizowane są wątki badań teatrologicznych. Dlatego istotna wydaje się próba ukierunkowania badawczej refleksji na źródła, z jakich czerpali obaj twórcy, kształtując swą poetycką wrażliwość, koncepcję człowieka i świata uzewnętrznianą w strukturze dzieł dramatycznych, wpisaną w myśl teatralną, poglądy na temat misji sztuki i aktora. Rekonesansowa próba porównania kompozycji wczesnych dramatów Zegadłowicza i Wojtyły wskazuje na wspólne korzenie postrzegania roli teatru i model dramaturgii wyrastającej z tradycyjnych, misteryjno-moralitetowych form teatralnych. Widoczne są również podobne kierunki i obszary artystycznych penetracji, pojmowania estetycznych kanonów sztuki, wartości regionalnej kultury, przy równoczesnej odrębności światopoglądu i twórczości obu artystów.

Słowa kluczowe: Karol Wojtyła; Emil Zegadłowicz; teatr pierwszej połowy XX wieku; teatr i dramat religijny 


\section{KAROL WOJTYŁA AND EMIL ZEGADŁOWICZ - SIMILAR OR DIFFERENT? \\ ON THE CONCEPT OF THEATRE}

Sum mary

This article is a comparative study of the concept of the theatre of Karol Wojtyła and Emil Zegadłowicz. Although many works have been devoted to the youthful literary output and theatrical activity of Wojtyła, the themes of theatre studies have still not yet been fully analysed. Therefore, it would seem to be important to research those sources from which both artists drew, those that shaped their poetic sensitivity, their concept of man and their concept of the world as externalised in the structure of the dramatic works, inscribed in their theatrical thought and in their views on the mission of art and the actor. An attempt to compare the compositions of Zegadłowicz's and Wojtyła's early plays points to the common roots of the perception of the role of theatre and a model of dramaturgy arising from traditional, mystery-morality plays. Similar trends and areas of artistic penetration, the comprehension of the aesthetic canons of art and the value of regional culture are also visible, while the world-views and creativity of both artists are separate.

Keywords: Karol Wojtyła; Emil Zegadłowicz; theatre of the first half of the 20th century; religious theatre and drama 